\title{
Langmuir Aggregation of Chromophore in Biomacromolecule and its Application: Interaction of Picramine CA (PCA) with Proteins
}

\author{
HONG-WEN GAO*, JIA-XIANG YANG, JUN JIANG and LIN-QIAN YU \\ Anhui University, School of Chemistry and Chemical Engineering, Hefei-230039, People's Republic of China
}

(Received 11 September 2000; In final form 4 May 2001)

\begin{abstract}
The microphase adsorption-spectral correction (MPASC) technique has been described. The formation of microelectrostatic fields in macromolecule is proposed and it causes the aggregation of a chromophore in protein. We have studied the interaction of picramine CA (PCA) with five proteins: bovine serum albumin (BSA), human $\gamma$ globulin $(\gamma-\mathrm{G})$, bovine hemoglobin $(\mathrm{Hb})$, horse myoglobin (Mb) and ovalbumin (OVA). Results show that at $\mathrm{pH}$ 2.21, the adsorption ratios of PCA to BSA, $\gamma-\mathrm{G}, \mathrm{Hb}, \mathrm{Mb}$ and OVA are 46, 54, 35, 15 and 21, respectively, their adsorption constants $3.17 \times 10^{5}, 6.58 \times 10^{4}, 1.40 \times 10^{5}$, $8.99 \times 10^{4}$ and $1.68 \times 10^{5}$ and their absorptivities $3.56 \times 10^{5}, 3.06 \times 10^{5}, 2.91 \times 10^{5}, 1.10 \times 10^{5}$ and $1.97 \times$ $10^{5} 1 \mathrm{~mol}^{-1} \mathrm{~cm}^{-1}$ at $630 \mathrm{~nm}$. The analysis of samples has given the satisfactory result.
\end{abstract}

Keywords: MPASC technique; Protein; Picramine CA (PCA); Microelectrostatic field; Langmuir aggregation

\section{INTRODUCTION}

At present, more and more biochemists are interested in research on supramolecular chemistry. Understanding the interaction between protein and a chromphore is important in biochemistry and quantitative determination of proteins is useful in clinical tests and laboratory practice. The conventional methods include the Biuret [1], Bradford [2], Lowry [3], Bromcresol green [4], and resonance light scattering (RLS) technique [5-8]. However, the interaction between biological macromolecules and organic dyes has not been elucidated satisfactorily and earlier observations have not been explained

\footnotetext{
*Corresponding author. E-mail: gaohongw@mail.hf.ah.cn
}

Fax: 0086-551-5106110 clearly and reasonably, e.g. the Pesavento equation [9], and Scatchard model [10].

Some chromophores, e.g. Bromophenol blue, Neutral red as the adsorption indicators are usually used in the determination of halogen anions. The same color change was observed when we used proteins in place of halogen anions. Consequently, the interaction of biological macromolecules with chromophore has the same mechanism as the precipitation adsorption reaction. Commonly, the biological macromolecule contains a complex spatial structure. The winding, folds, coils and other arrangement lead to many holes, gullies and helix grooves. Many secondary bonds are close to each other, such as van der Waals bonds, salt bonds, hydrogen bonds. The charge density becomes very high around the holes, grooves and gullies. The like charges aggregate together to form many microelectrostatic fields as shown in Fig. 1(1). They will selectively attract charged organic compounds till kinetic equilibrium (Fig. 1(2)). The existence of a microelectrostatic field is the basis of the adsorption of a chromophore in macromolecules. In addition, we found that the equilibrium equation of the conventional biochemical reaction is same as the Langmuir adsorption equation [11]. The microelectrostatic field is so narrow that organic molecules (with charge) were adsorbed only in a monolayer. Therefore, the aggregation of a chromophore in macromolecule is regarded as monolayer adsorption of the microelectrostatic field. Such an adsorption equilibrium occurs: L(aqueousphase, $\left.C_{L}\right) \Leftrightarrow M L_{N}$ (macromolecular phase, $C_{M}$ ) in $\mathrm{L}-\mathrm{M}$ solution. The 


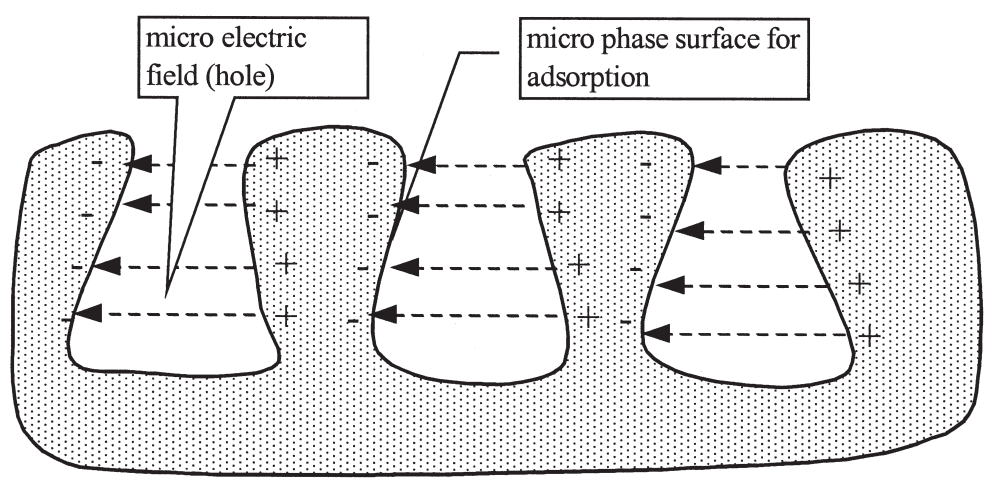

(1) Formation of electrostatic field

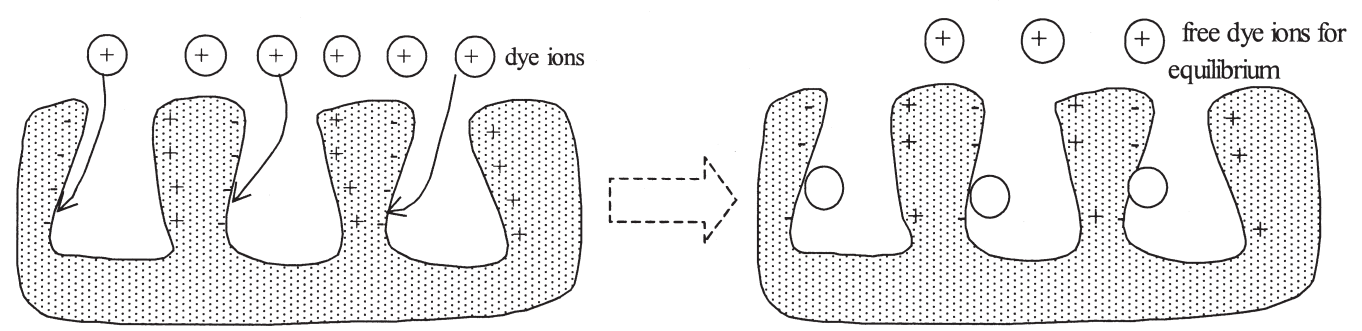

(2) Aggregation of dye molecules in field

FIGURE 1 (1) The formation of microelectrostatic field in macromolecule and (2) the adsorption process of dye molecules in microphase surface.

Langmuir adsorption equation may be used as follows

$$
\gamma=\frac{K N C_{L}}{1+K C_{L}}
$$

where $K$ is the equilibrium constant and $C_{L}$, the concentration of the excess $L . N$ indicates the maximal adsorption ratio of $L$ to $M$ and $\gamma$ the molar ratio of $L$ adsorbed to $M$. $K$ is calculated from Eq. (1). Both $C_{L}$ and $\gamma$ are calculated by means of [12]:

$$
\begin{gathered}
\gamma=\eta \times \frac{C_{L 0}}{C_{M}} \\
C_{L}=(1-\eta) C_{L 0}
\end{gathered}
$$

where

$$
\eta=\frac{A_{\mathrm{c}}-\Delta A}{A_{0}}
$$

where both $C_{M}$ and $C_{L 0}$ are the concentration of the $M$ and $L$ added initially and $\eta$ indicates the effective fraction of $L . A_{\mathrm{c}}, A_{0}$ and $\Delta A$ are the real absorbance of the $M-L$ product, the measurement absorbance of the reagent blank against water and that of the $M-L$ solution against reagent blank directly measured at the peak wavelength $\lambda_{2}$. Within increase in $L$ concentration, $\gamma$ will approach a maximum $N$. The
$A_{\mathrm{c}}$ is calculated by means of [13]:

$$
A_{\mathrm{c}}=\frac{\Delta A-\beta \Delta A^{\prime}}{1-\alpha \beta}
$$

where $\Delta A^{\prime}$ indicates the absorbance of the $M-L$ solution measured respectively at the valley absorption wavelength $\lambda_{1}$. Usually, $\alpha$ and $\beta$ are the correction constants [13] and they are calculated by measuring directly $M L_{N}$ and $L$ solutions. In addition, the absorptivity (real $\varepsilon_{r}^{\lambda 2}$ not apparent $\varepsilon_{a}^{\lambda_{2}}$ ) of the adsorption product $M L_{N}$ at $\lambda_{2}$ is also directly calculated by the means of:

$$
\varepsilon_{r}^{\lambda_{2}}=\frac{N A_{\mathrm{c}}}{\delta \gamma C_{M}}
$$

where $\delta$ is the cell thickness $(\mathrm{cm})$ and the others have the same meaning as in the equations above. In addition, the adsorption constant $(K)$ of the aggregate $M L_{N}$ can also be calcualted by the relation:

$$
K=\frac{N_{\gamma}}{(N-\gamma)\left(N C_{L 0}-\gamma C_{M}\right)}
$$

We find that the Pesavento hypothesis and Scatchard model are same as the Langmuir adsorption Eq. (1). Consequently, in fact, both, the Pesavento hypothesis and Scatchard model are just microelectrostatic 
<smiles>CC(C)COc1cc2cc(S(=O)(=O)O)cc(O)c2c(O)c1N=Nc1c(O)cc([N+](=O)[O-])cc1[N+](=O)[O-]</smiles>

field's adsorption between macromolecules and small dye molecules. The combination of both the Langmuir adsorption and the spectral correction technique will provide a very helpful experimental strategy for study of aggregation of chromophore on sufractant micelle. The method is called microphase adsorption-spectral correction technique (MPASC). In the present report, we have studied the interaction between proteins and picramine CA (PCA). PCA is one of chromotropic acid azo derivant, which was ever used in the determination of some organic metal ions, e.g. Zr, Sc, rare earth and so on. The structure of the chromophore is shown in Scheme 1

It is sensitive to aggregate in protein. The aggregation of PCA in protein (BSA, $\mathrm{Hb}, \mathrm{Mb}$, OVA and $\gamma-G$ ) accords with the Langmuir adsorption. Results showed that at $\mathrm{pH} 2.21$, the maximal adsorption ratios of $\mathrm{BSA}, \gamma-\mathrm{G}, \mathrm{Hb}, \mathrm{Mb}$ and OVA to PCA are 46, 48, 35, 15 and 13, respectively, and their adsorption constants $K_{\mathrm{BSA}-\mathrm{PCA}}=3.17 \times 10^{5}$, $K_{\gamma-\mathrm{G}-\mathrm{PCA}}=6.58 \times 10^{4}, \quad K_{\mathrm{Hb}-\mathrm{PCA}}=1.40 \times 10^{5}$, $K_{\mathrm{Mb}-\mathrm{PCA}}=8.99 \times 10^{4}$ and $K_{\mathrm{OVA}-\mathrm{PCA}}=1.68 \times 10^{5}$.

\section{RESULTS AND DISCUSSION}

\section{Spectra}

The adsorption between PCA and proteins (BSA as representative) was carried out. At $\mathrm{pH} 2.21$, the absorption spectra of BSA-PCA solution is shown in Fig. 2, where $0.50 \mathrm{mg}$ of BSA and $0.50 \mu \mathrm{mol}$ of PCA were added. From curves 1 and 2, we find that the peak of PCA is located at $550 \mathrm{~nm}$ and that of BSAPCA product at $590 \mathrm{~nm}$. We observe that the product has a longer peak wavelength than PCA. The spectral red shift is only $40 \mathrm{~nm}$. Therefore, the excessive PCA will interfere with the real absorbance measurement of the product. From curve 3, representing the relative absorption spectrum of PCA-protein solution against PCA solution, we observe that the peak is located at $630 \mathrm{~nm}$ and the valley at $510 \mathrm{~nm}$. So such two wavelengths were used in this work. From curves 1 and 2, the correction coefficients were calculated to be $\beta=0.239$ and $\alpha=$ 0.714. Because of high $\beta$, the spectral correction method should be used in place of the ordinary spectrophotometry.

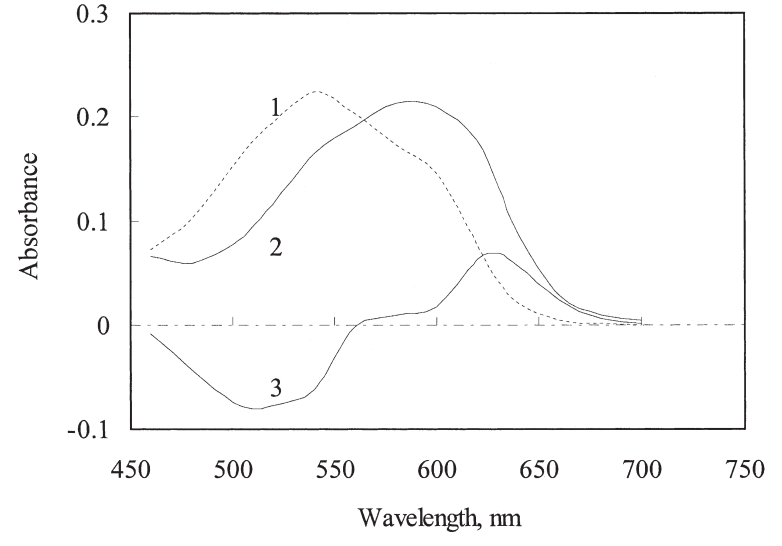

FIGURE 2 Absorption spectra of PCA and its BSA solutions at pH 2.21: (1) $0.200 \mu \mathrm{mol}$ of PCA, (2) solution initially containing $0.200 \mu \mathrm{mol}$ of PCA and $10 \mathrm{mg}$ of BSA, (3) solution initially containing $0.200 \mu \mathrm{mol}$ of PCA and $0.500 \mathrm{mg}$ of BSA. Both 1 and 2 against water and 3 against the blank.

\section{Effect of PH}

By varying $\mathrm{pH}$ of solution, the absorption of the BSA-PCA solution was measured and the ratio of PCA to BSA is shown in Fig. 3. We observe that lower the $\mathrm{pH}$ changes, higher the adsorption ratio becomes. This is because the protonation reaction of PCA occurs in acidic solution. PCA cations are attracted easily and closely on microphase surface in proteins.

\section{Effect of Ion Strength, Surfactants, Temperature and Interaction Time}

The influence of ionic strength of solution on binding ratio is shown in Fig. 4(1). Between the ionic strength 0 and $0.4 \mathrm{M}$, the ratio of PCA to BSA becomes lower with increase in ionic strength. As more ions were attracted into microelectrostatic fields to take up the microphase surface, this causes decrease of the adsorption ratio.

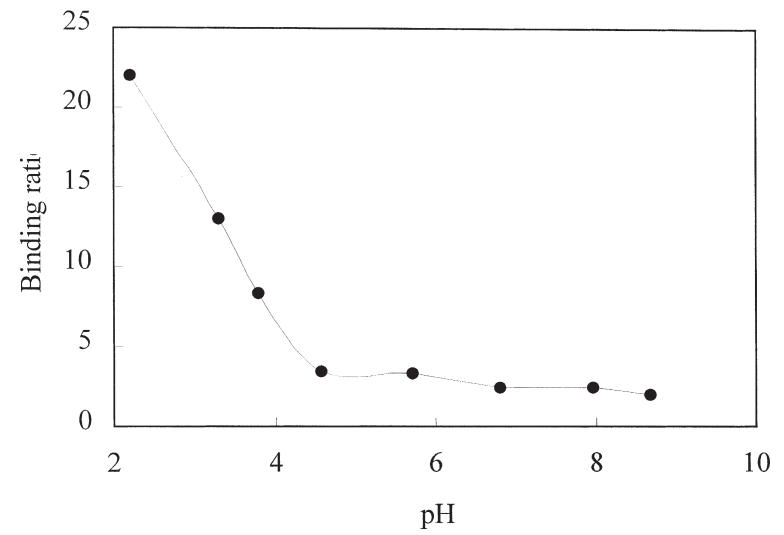

FIGURE 3 Effect of $\mathrm{pH}$ on $\gamma$ (solution initially containing $0.200 \mu \mathrm{mol}$ of PCA and $0.50 \mathrm{mg}$ of BSA). 

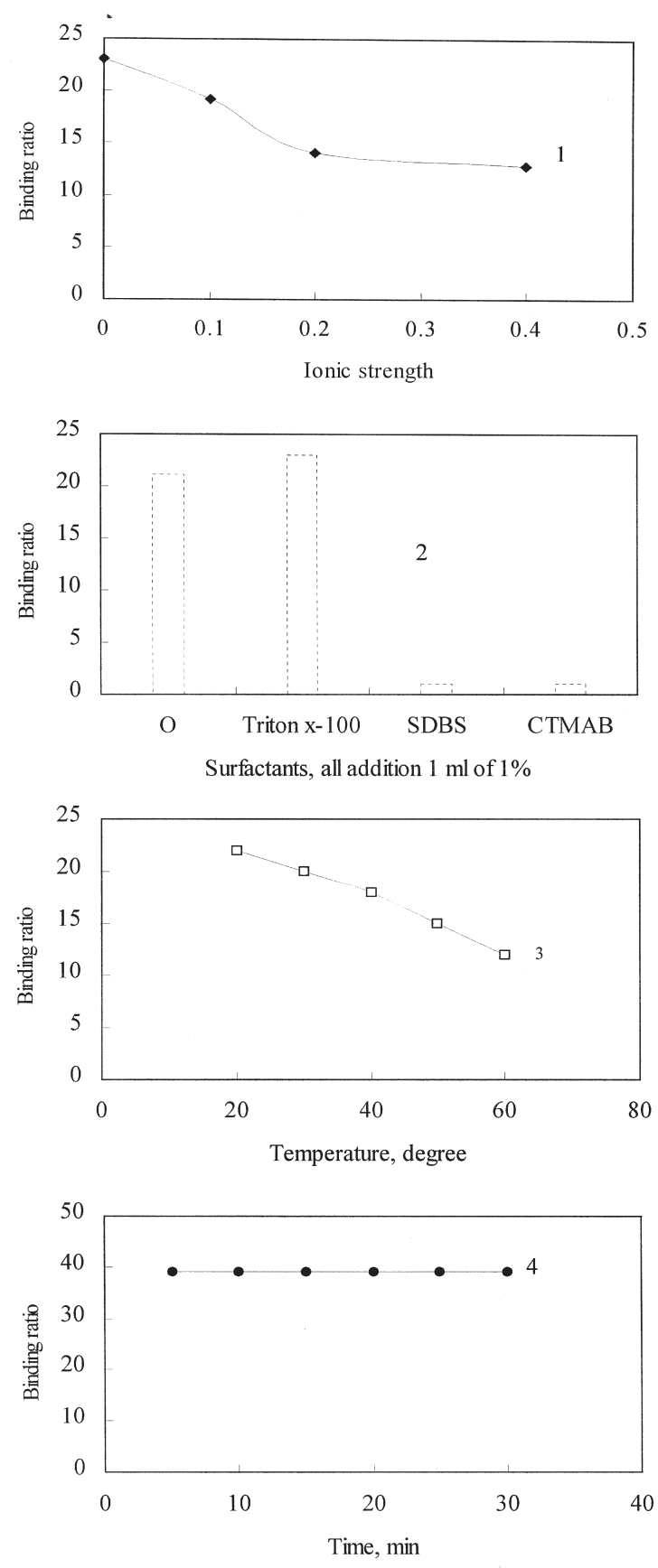

FIGURE 4 Effect of ionic strength (1), surfactants (2), temperature (3) and the interaction time (4) on $\gamma$ (solutions initially all containing $0.200 \mu \mathrm{mol}$ of PCA and $0.50 \mathrm{mg}$ of BSA).

The effect of various surfactants on the binding ratio of PCA to BSA is shown in Fig. 4(2). The use of ionic surfactants CTMAB and SDBS decreases the adsorption ratio because they can also be adsorbed closely in place of PCA molecules. The non-ionic surfactant Triton $\mathrm{x}-100$ does not affect the binding ratio because it is neutral.

At various temperatures, the relationship of the binding ratio with PCA is shown in Fig. 4(3). The ratio remains almost constant with increase in temperature. It indicates that the adsorption of

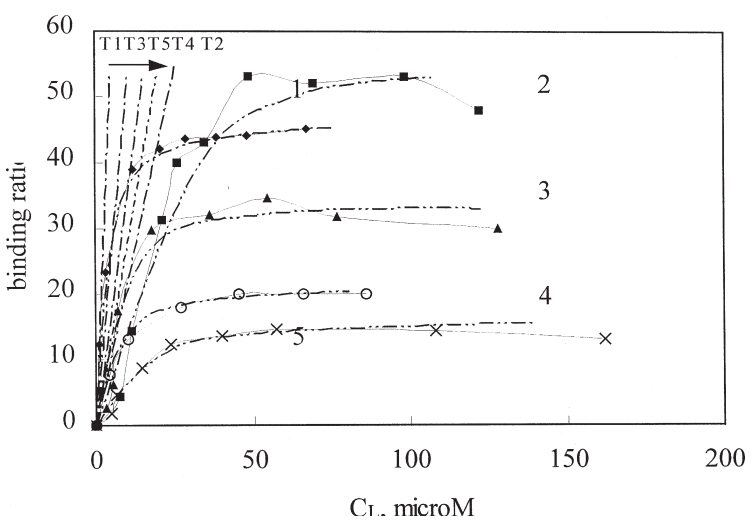

FIGURE 5 Relationship between $\gamma$ and $C_{L}$. Solutions initially containing: (1) $0.500 \mathrm{mg}$ of BSA, (2) $1.00 \mathrm{mg}$ of $\gamma-\mathrm{G}$, (3) $0.500 \mathrm{mg}$ of $\mathrm{Hb}$, (4) $0.500 \mathrm{mg}$ of $\mathrm{Mb}$, (5) $0.500 \mathrm{mg}$ of OVA.

PCA is too close and strong for higher temperature to desorb it form protein macromolecule. So the formed aggregate is quite stable.

From Fig. 4(4), at room temperature, the interaction between BSA and PCA is complete in $5 \mathrm{~min}$. So, the monolayer adsorption of PCA in protein is rapid.

\section{Effect of PCA Concentration}

By varying the addition of PCA solution, the absorption of the various protein solutions was measured. Calculated $\gamma$ and $C_{L}$ of each solution. Their relationship is shown in Fig. 5, where the dashed lines indicated the Langmuir regression adsorption, solid lines, the measured absorption and dotted lines, the tangent of grid origin. We find that the measurement points are close to the Lagmuir adsorption curve. Therefore, the aggregation of PCA in proteins agrees to the monolayer adsorption. To analyze the extended constant of curves $1-5$, we obtain the binding ratios of PCA to BSA, $\gamma-\mathrm{G}, \mathrm{Hb}, \mathrm{Mb}$ and OVA to be $46,54,35,15$ and 21 , respectively. From the tangent lines $\mathrm{T} 1-\mathrm{T} 5$ of curves at $\mathrm{O}$ point, we calculate the binding constants of products of PCA with BSA, OVA, $\mathrm{Hb}, \gamma-\mathrm{G}$ and $\mathrm{Mb}$ to be $K=$ $3.56 \times 10^{5}, 1.68 \times 10^{5}, 1.10 \times 10^{5}, 5.75 \times 10^{4}$ and $8.88 \times$ $10^{4}$, respectively. Additionally, we prepared the solutions (given in Table I) for another determination [13] of $K$ and real absorptivity $(\varepsilon)$ of the product from Eqs. (6) and (7). The results are given in Table I. We find that the mean $K$ of six replicated determinations of each solution in Table I is similar to that above. To see Table I, the binding constants of products arrange as BSA, OVA, $\mathrm{Hb}, \mathrm{Mb}$ and $\gamma-\mathrm{G}$ in high to low order. From $\varepsilon$ in Table I, the higher the absorptivity of the product became, larger the binding ratio $N$ is. In the determination of the adsorption ratio and equilibrium constant, the spectral correction method had special advantage in operation and principle by contrast to classical methods such as molar ratio [14], 
TABLE I Determination of the binding ratio, equilibrium constant and real asborptivity of the adsorption products at $\mathrm{pH} 2.21$ (six replicated determination)

\begin{tabular}{lccc}
\hline Interaction & $\gamma / N$ & $K$ & $\varepsilon\left(1 \mathrm{~mol}^{-1} \mathrm{~cm}^{-1}\right.$ at $630 \mathrm{~nm}^{2}$ \\
\hline BSA $(0.500 \mathrm{mg})-\mathrm{PCA}(0.200 \mu \mathrm{mol})$ & $(23.4 \pm 1.4) / 48$ & $(3.17 \pm 0.51) \times 10^{5}$ & $3.56 \times 10^{5}$ \\
OVA $(0.500 \mathrm{mg})-\mathrm{PCA}(0.200 \mu \mathrm{mol})$ & $(13.2 \pm 0.81) / 21$ & $(1.68 \pm 0.33) \times 10^{5}$ & $1.97 \times 10^{5}$ \\
$\mathrm{Hb}(0.500 \mathrm{mg})-\mathrm{PCA}(0.200 \mu \mathrm{mol})$ & $(17.5 \pm 1.6) / 35$ & $(1.40 \pm 0.26) \times 10^{5}$ & $2.91 \times 10^{5}$ \\
$\gamma-\mathrm{G}(1.00 \mathrm{mg})-\mathrm{PCA}(0.400 \mu \mathrm{mol})$ & $(31.4 \pm 2.3) / 54$ & $(6.58 \pm 1.02) \times 10^{4}$ & $3.06 \times 10^{5}$ \\
$\mathrm{Mb}(0.500 \mathrm{mg})-\mathrm{PCA}(0.400 \mu \mathrm{mol})$ & $(8.7 \pm 0.42) / 15$ & $(8.99 \pm 1.13) \times 10^{4}$ & $1.10 \times 10^{5}$ \\
\hline
\end{tabular}

TABLE II The linear regression equations for determination of proteins with PCA at pH 2.21 and in the presence of EDTA

\begin{tabular}{lccc}
\hline Protein & Linear scope $(\mathrm{mg} / 10 \mathrm{ml})$ & Regression equation at $630 \mathrm{~nm}$ & Correlation coefficient \\
\hline $\mathrm{BSA}$ & $0-1.5$ & $A_{\mathrm{c}}=0.231 x+0.004$ & 0.9947 \\
$\mathrm{OVA}$ & $0-1.2$ & $A_{\mathrm{c}}=0.256 x-0.005$ & 0.9980 \\
$\mathrm{Hb}$ & $0-2.0$ & $A_{\mathrm{c}}=0.217 x-0.017$ & 0.9998 \\
$\gamma-\mathrm{G}$ & $0-1.2$ & $A_{\mathrm{c}}=0.267 x+0.006$ & 0.9989 \\
$\mathrm{Mb}$ & $0-2.0$ & $A_{\mathrm{c}}=0.313 x-0.018$ & 0.9990 \\
\hline
\end{tabular}

continuous variation [15] and equilibrium movement [16].

\section{Calibration Graph and Precision}

The standard series of proteins were prepared and measured at $\mathrm{pH} 2.21$ where $1.0 \mathrm{ml}$ of PCA solution was added. The linear regression equations are given in Table II. The slopes of the equations are between 0.217 and 0.313 and the mean is 0.257 . The maximal deviation is only $20 \%$. It indicates that the absorption per milligram of protein is almost similar despite of various structures. So constant number of amino acid residues consists of one microelectrostatic field by folding. It is convenient for total proteins in samples to be determined only by one calibration graph, e.g. the OVA-PCA regression equation. Additionally, the adsorption ratio $(\gamma)$ and the effective fraction $(\eta)$ of PCA in each solution above are shown in Fig. 6. All $\gamma$ reach peak after the addition of $0.80 \mathrm{mg}$ of

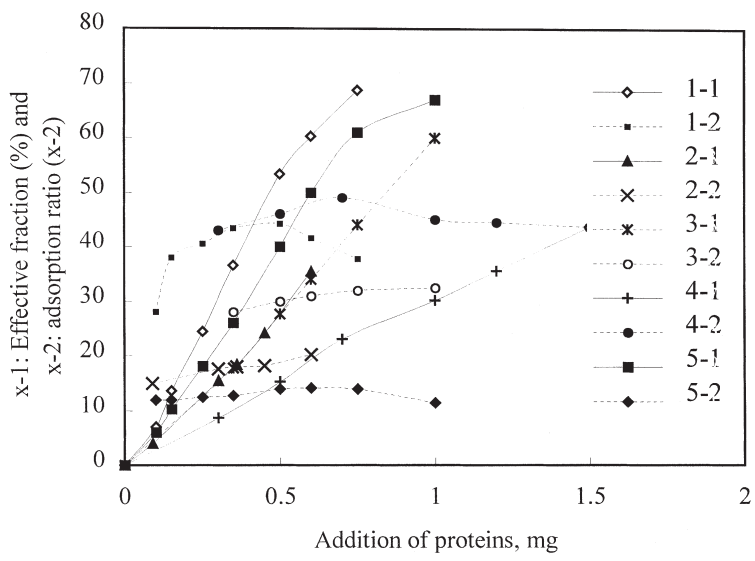

FIGURE 6 Effect of protein concentration on $\eta(x-1)$ and $\gamma$ $(x-2)$ where $1.00 \mu \mathrm{mol}$ of PCA was added initially: (1) BSA, (2) OVA, (3) $\mathrm{Hb}$, (4) $\gamma-\mathrm{G}$, (5) Mb. proteins. The peak $\gamma$ increases with increase in Dalton formula weight of proteins. This also confirms that the aggregation of PCA in proteins is in relation to only the number of amino acid residues in protein.

For 0.010 of $A_{\mathrm{c}}$, the detection limit was calculated to be $0.04 \mathrm{mg}$ of protein in $10 \mathrm{ml}$ of solution. Six replicated determinations of $1.00 \mathrm{mg}$ of BSA were carried out. The mean was $1.06 \pm 0.03 \mathrm{mg}$ and the recovery of standard BSA $106 \%$ with the relative standard deviation (RSD) $2.43 \%$.

\section{Effect of Foreign Ions}

By adding EDTA- $\mathrm{Na}_{2}$ solution $(0.5 \mathrm{ml}$ of $5 \%)$ in protein solution, the influence of foreign substances including ions and organic compounds, on the determination of protein was tested at $\mathrm{pH}$ 2.21. Because EDTA may complex most of metal ions, the high concentration of metal ions may be allowed. None of the following ions affected the direct determination of $0.50 \mathrm{mg}$ of BSA (less than $10 \%$ error): $1 \mathrm{mg}$ of $\mathrm{K}^{+}, \mathrm{Ca}(\mathrm{II}), \mathrm{SO}_{4}^{2-}, \mathrm{CO}_{3}^{2-}, 0.5 \mathrm{mg}$ of $\mathrm{Cl}^{-}$, $\mathrm{F}^{-}, \mathrm{PO}_{4}^{3-}, \mathrm{NO}_{3}^{-}, \mathrm{SO}_{3}^{2-}, \mathrm{C}_{2} \mathrm{O}_{4}^{2-}$, triton $\mathrm{x}-100, \mathrm{Ac}^{-}$, ctDNA, yRNA, glucose, amino acid, $\mathrm{Mg}$ (II), $0.1 \mathrm{mg}$ of acetone, ethanol, $\mathrm{NH}_{4}^{+}, \mathrm{Mn}(\mathrm{II}), \mathrm{Zn}(\mathrm{II}), \mathrm{Ti}(\mathrm{IV}), \mathrm{Pb}(\mathrm{II})$, $\mathrm{Ni}(\mathrm{II}), \mathrm{Co}(\mathrm{II}), \mathrm{Sn}(\mathrm{II}), \mathrm{Cd}(\mathrm{II}), 0.02 \mathrm{mg}$ of $\mathrm{Fe}(\mathrm{III}), \mathrm{Al}(\mathrm{III})$, $\mathrm{Cu}$ (II), $\mathrm{Hg}$ (II). The ion surfactants, e.g. CTMAB and SDBS can bring the negative interference.

\section{Sample Analyzed}

Two samples were determined. The first sample was prepared by diluting $1.00 \mathrm{ml}$ of Duoqi Children Drink to $100 \mathrm{ml}$ with deionized water and the other was prepared with drinking water as background aqueous by adding drops of protein and the following compounds or ions: $1 \mathrm{mg}$ of $\mathrm{Ca}(\mathrm{II})$, 
TABLE III Determination of proteins in samples in the presence of EDTA (rec indicates recovery)

\begin{tabular}{|c|c|c|}
\hline Sample & Added & Found (mg) \\
\hline \multirow[t]{2}{*}{$\begin{array}{l}\text { 1\# from Duoqi Drink } \\
\text { (protein content about } 2 \% \text { ) }\end{array}$} & $0.40 \mathrm{ml}$ & $\begin{array}{c}0.912 \pm 0.021 \\
\text { RSD. } 2.87 \%\end{array}$ \\
\hline & $0.500 \mathrm{mg}$ of OVA & $\begin{array}{l}1.448 \pm 0.050 \\
\text { rec. } 107.3 \%\end{array}$ \\
\hline \multirow[t]{5}{*}{$\begin{array}{l}\text { 2\# Drinking water background } \\
\text { (three replicated determinations of } 5.0 \mathrm{ml} \text { ) }\end{array}$} & $0.500 \mathrm{mg}$ of BSA & $\begin{array}{l}0.487 \pm 0.021 \\
\text { rec. } 97.4 \%\end{array}$ \\
\hline & $1.00 \mathrm{mg}$ of $\gamma-\mathrm{G}$ & $\begin{array}{l}0.938 \pm 0.040 \\
\text { rec. } 93.8 \%\end{array}$ \\
\hline & $0.500 \mathrm{mg}$ of $\mathrm{Hb}$ & $\begin{array}{l}0.465 \pm 0.024 \\
\quad \text { rec. } 93.0 \%\end{array}$ \\
\hline & $0.500 \mathrm{mg}$ of $\mathrm{Mb}$ & $\begin{array}{l}0.492 \pm 0.018 \\
\text { rec. } 98.4 \%\end{array}$ \\
\hline & $0.500 \mathrm{mg}$ of OVA & $\begin{array}{l}0.511 \pm 0.022 \\
\text { recovery } 102.2 \%\end{array}$ \\
\hline
\end{tabular}

ethanol, acetate, ctDNA, yRNA, glucose and $\mathrm{PO}_{4}^{3-}$, $0.5 \mathrm{mg}$ of $\mathrm{Ca}(\mathrm{II}), \mathrm{Mg}(\mathrm{II}), \mathrm{Cl}^{-}, 0.1 \mathrm{mg}$ of $\mathrm{F}^{-}, \mathrm{Cu}(\mathrm{II})$, $\mathrm{Mn}(\mathrm{II}), \mathrm{Zn}(\mathrm{II})$ and $0.02 \mathrm{mg}$ of $\mathrm{Pb}(\mathrm{II})$. The determination of samples and recovery of proteins are given in Table III. Calculated the protein content of the original drink to be $2.3 \%$ and it is close to the "about $2 \%$ protein" marked the container. The recovery of OVA added in the first sample was $107.3 \%$ together with the relative standard deviation $2.87 \%$. The recovery of various proteins added in second sample is between 93.0 and $102.2 \%$.

The investigation to the aggregation of PCA and the other chromophores [17] in proteins supports the monolayer adsorption and the hypothesis of the microelectrostatic field. Though MPASC technique has not given the higher sensitivity than other methods such as RLS [8], it meets precision and accuracy criteria and offers the additional benefits of simplicity and versatility. We understand that the classical method can still play an important role in the macromolecular behaviour and the determination of the property constants.

\section{MATERIALS AND METHODS}

\section{Materials}

Absorption spectra were recorded with a UV/VIS 265 spectrophotometer (Shimadzu, Kyoto, Japan). DDS-11A conductivity meter (Tianjin Second Analytical Instrument Works) was used to measure conductivity together with a DJS-1 conductivity immersion electrode (electrode constant 0.98) (Shanghai Tienkuang Device Works) in the production of deionized water of $0.5-1 \mu \Omega^{-1} \mathrm{~cm}^{-1}$. The $\mathrm{pH}$ of the solution was measured with a pHS-2C acidity meter (Leici Instrument, Shanghai, China) and Model 620D pH Pen (Shanghai Ren's Electrostatic). The temperature was adjusted and remained constant in a Model 116R, electrostatically heated thermostatic bath (Changjiang Test Instrument of Tongjiang, China).

Stock standard solutions of proteins were prepared by dissolving the commercial bovine serum albumin (BSA) (Beitai Biochemical, Chinese Academy Sciences, Beijing, China), human $\gamma$-globulin ( $\gamma$ G), (Serva, Heidelberg, Germany), bovine hemoglobin ( $\mathrm{Hb}$, Dongfeng Biological Technological), horse myoglobin $(\mathrm{Mb})$ (Shanghai Chemical Reagents Center) and ovalbumin (OVA) (Shanghai Chemical Reagents Center) in non-ionic water. The $\gamma-G$ solution is $1.00 \mathrm{mg} \mathrm{ml}^{-1}$ and the others $0.500 \mathrm{mg} \mathrm{ml}^{-1}$.

PCA solution $(1.00 \mathrm{mM})$ was prepared by dissolving $0.2650 \mathrm{~g}$ of PCA (purified and provided by Changke Regent Institute, Shanghai) in $500 \mathrm{ml}$ of deionized water. The Britton-Robinson buffer solutions between $\mathrm{pH} 2.21$ and 8.69 were prepared to control the acidity of the interaction solution. $2 \mathrm{M}$ $\mathrm{NaCl}$ was used to adjust the ionic strength of the aqueous solutions. $\mathrm{Na}_{2}$-EDTA solution $(5 \%)$ was prepared to mask the foreign metallic ions co-existed possibly in the practical samples. All reagents were of analytical grade and used without further purification. The surfactant solutions, Triton x-100, sodium dodecylbenzene sulfonate (SDBS) and cetyltrimethylammonium bromide (CTMAB) (all $1 \%$ ), were prepared for testing their effect on the sensitivity.

\section{Methods}

Into a $10 \mathrm{ml}$ calibrated flask were added an appropriate working solution of proteins or proteins, $1.0 \mathrm{ml}$ of Britton-Robinson buffer solution and appropriate PCA solution. The mixture was then diluted to $10 \mathrm{ml}$ with deionized water and mixed thoroughly. All the absorption measurements were obtained against the blank treated in the same way without proteins. 
In the determination of proteins in samples, the masking reagent, $0.5 \mathrm{ml}$ of $\mathrm{Na}_{2}$-EDTA solution (5\%) was added to complex metal ions, e.g. $\mathrm{Pb}(\mathrm{II}), \mathrm{Cd}(\mathrm{II})$, $\mathrm{Hg}$ (II) and so on. The next successive operation is same as the above procedure.

\section{Acknowledgements}

Financial support from the Natural Science Foundation of Anhui Province is gratefully acknowledged. I thank my colleagues Fu-Xin Xie and XiangTai Kong for the technical assistance.

\section{References}

[1] Bradford, M.M. (1976), Anal. Biochem. 72, 245.

[2] Li, N. and Tong, S.Y. (1995), Anal. Lett. 28, 1763.
[3] Li, N. and Tong, S.Y. (1994), Talanta 41, 1657.

[4] Pasternack, R.F., Gibbs, E.J. and Villafranca, J.J. (1983), Biochemistry 22, 2406.

[5] Arlinghaus, H.F. and Kwoka, M.N. (1997), Anal. Chem. 69, 3747.

[6] Huang, C.Z., Li, Y.F. and Mao, J.G. (1998), Analyst 123, 1401

[7] Ma, C.Q., Li, K.A. and Tong, S.Y. (1997), Bull. Chem. Soc. Jpn. 70, 129.

[8] Pastermack, R.F., Bustamante, C. and Collings, P.J. (1993), J. Am. Chem. Soc. 115, 5393.

[9] Pesavento, M. and Profumo, A. (1991), Talanta 38, 1099.

[10] Scatchard, G., Scheinerg, I.H. and Armstrong, S.H. (1950), J. Am. Chem. Soc. 72, 535.

[11] Langmuir, I. (1918), J. Am. Chem. Soc. 40, 1361.

[12] Gao, H.W. (1995) Recl. Trav. Chim. Pays-Bas 114, 61.

[13] Gao, H.W., Zhang, S.Y. and Ye, S.M. (2000), J. AOAC Intern. 83, 231.

[14] Tikhonov, V.N. (1975), Zh. Anal. Khim. 30, 1501.

[15] Likussar, W. (1973), Anal. Chem. 45, 1926.

[16] Laearev, A.I. (1975), Zavod. Lab. 41, 534.

[17] Gao, H.W., Jiang, J. and Yu, L.Q. (2001), Analyst 126, 528. 